\title{
Melaleuca alternifolia Essential Oil against the Lesser Mealworm (Alphitobius diaperinus) and Its Possible Effect on the Soil Fauna

\section{mAuthor(s)}

\author{
Volpato $A^{\prime}$ \\ Lorenzetti WR' \\ Zortea $T^{\prime}$ \\ Giombelli LCDD' \\ Baretta $D^{\prime}$ \\ Santos RCV ${ }^{11}, \|$ \\ Vaucher RA" \\ Raffin RPIV \\ Souza ME"I,II \\ Stefani LM' \\ Boligon AAv \\ Athayde $\mathrm{ML}^{\mathrm{V}}$ \\ Silva AS da'
}

Animal Science Department, Universidade do Estado de Santa Catarina, Chapecó, SC, Brazil.

" Microbiology and Parasitology Department, Universidade Federal de Santa Maria, Santa Maria, RS, Brazil.

III Microbiology Laboratory, Programa de Pós-Graduação em Nanociências, Centro Universitário Franciscano, Santa Maria, RS, Brazil.

Iv Nanotechnology Laboratory, Programa de Pós-Graduação em Nanociências, Santa Maria, RS, Brazil.

$\checkmark$ Phytochemistry Laboratory, Universidade Federal de Santa Maria, Santa Maria, RS, Brazil.

\section{Mail Address}

Corresponding author e-mail address

Aleksandro da Silva

Rua Beloni Trombeta Zanin, 68E Bairro Santo Antonio, Chapecó, SC, Brazil. Postal code: 8981-630.

Phone: (049) 2049-9560

Email: aleksandro_ss@yahoo.com.br

\section{Eeywords}

Alphitobius diaperinus, essential oil, natural products, nanotechnology, pest management.

\section{ABSTRACT}

The aim of this study was to evaluate the in vitro bioactivity of tea tree (Melaleuca alternifolia) essential oil against larvae and adult forms of lesser mealworms (Alphitobius diaperinus) and its influence on the soil fauna. Tests were performed in triplicate using pure tea tree oil (TTO; 1, 5, 10, 25, 50, and 100\%), TTO nanoparticles (1, 3, and $7.5 \%)$, or terpinen-4-ol, the main compound of the tea tree oil, at the same concentrations of TTO. Larvae and adult mortality occurred at concentrations up to 10 and $50 \%$ of TTO, respectively. No larvicidal or insecticidal effect of TTO nanoparticles was observed. Terpinen-4-ol showed insecticidal and larvicidal effect at concentrations higher than $25 \%$. The evaluation of TTO effect on soil organisms was performed by standard ecotoxicological tests (ISO) with the springtail species Folsomia candida. Only TTO was used for ecotoxicological tests in doses of 1, 5, $10,25,50$, and $100 \mathrm{mg} \mathrm{kg}^{-1}$ of soil. TTO had no negative effects on F. candida survival or reproduction. Therefore, it was concluded that M. alternifolia oil may be a new alternative for control of the lesser mealworm.

\section{INTRODUCTION}

The lesser mealworm Alphitobius diaperinus, Panzer, is one of the most common pests of poultry industry. Poultry housing provide optimal temperature and humidity conditions for its development, and the lesser mealworm feeds on poultry feed residues, fecal material, and dead birds (Gazoni et al., 2012). A. diaperinus is a potential carrier of several pathogens (viruses, fungi, bacteria, and protozoa) and it can be found everywhere inside poultry houses, hidden in cracks, beneath feeders and other areas (Silva et al., 2005). Pest management practices are routinely adopted, and the lesser mealworm control has been based on chemical insecticides applied on wood shavings used as litter. However, some flaws in these sanitary measures leads to litter reinfestation by $A$. diaperinus (Santos et al., 2009). It is known that these chemicals can also cause environmental contamination, affecting soil fauna survival and reproduction (Santos et al., 2012). Natural products may become alternative treatments, and therefore ecotoxicology tests are needed.

The use of natural products can be an alternative to control the lesser mealworm, as shown by Prado et al. (2013) using Cunila angustifolia. Plants from the Meliaceae family, particularly Melaleuca alternifolia, can be used for controlling parasites (Mulla \& Su 1999, Neves et al., 2012). The M. alternifolia oil is extracted from leaves and it is rich in terpinen4-ol, the most likely chemical compound responsible for antifungal and antibacterial activities (Carson \& Riley, 1993), as well as trypanocidal (Baldissera et al., 2014), insecticidal (Klauck et al., 2014) and acaricidal 
Volpato A, Lorenzetti WR, Zortea T, Giombelli LCDD, Baretta D,

Santos RC, Vaucher RA, Raffin RP,

Souza ME, Stefani LM, Boligon AA

Athayde ML, Silva AS da
Melaleuca alternifolia Essential Oil against the Lesser Mealworm (Alphitobius diaperinus) and Its Possible Effect on the Soil Fauna
(Walton et al., 2004) effects. On the other hand, the oil has problems due to its high volatility and insolubility in water. In order to manage these problems, increasing its efficacy, nanoparticles have been used quite often (Pazinato et al., 2014). This technology consists of the manipulation of the molecule to a nanometric size, organizing oil atoms into a desirable form, which has several advantages over conventional products, such as slow, gradual and controlled release, increased bioavailability and lower toxicity (Roco, 2001).

This study was performed to investigate the bioactivity of pure $M$. alternifolia oil (TTO), nanoparticles form (TTO nanoparticles) of this same oil, and its major compound (terpinen-4-ol) on larvae and adult forms of $A$. diaperinus. TTO effects on soil fauna were also assessed by means of ecotoxicity tests.

\section{MATERIALS AND METHODS}

\section{Oil forms and compounds}

Tea tree oil (TTO), TTO nanoparticles and terpinen4-ol were evaluated for their larvicidal and insecticidal activites. TTO was purchased from Importadora Química Delaware Ltda, Brazil. Terpinen-4-ol was purchased from Sigma Company. TTO nanoparticles were provided with the company Inventiva (Porto Alegre, Brazil), and the process of nanoparticle preparation was previously described by Pazinato et al. (2014). Solid lipid carriers were prepared with $7.5 \%$ of $M$. alternifolia essential oil using a patented process (Inventiva) based on highpressure homogenization. Cetyl palmitate was used as the solid lipid and polysorbate 80 as surfactant. The total solid concentration was $18.6 \%$. The particle size and zeta potential were evaluated on diluted samples (500x) using Zetasizer Nanoseries, Malvern. The pH was directly measured by use of a potentiomenter (Digimed, Brazil)

\section{TTO characterization}

Gas chromatography (GC) analyses were carried out using an Agilent Technologies 6890N GC-FID system, equipped with DB-5 capillary column $(30 \mathrm{~mm}$ $x 0.25 \mathrm{~mm}$; film thickness of $0.25 \mathrm{~mm}$ ) connected to a flame ionization detector (FID). The injector and detector temperatures were set at $280^{\circ} \mathrm{C}$. Helium was used as the carrier gas, at a flow rate of $1.3 \mathrm{~mL} / \mathrm{min}$. The thermal programmer was $50-300^{\circ} \mathrm{C}$ at a rate of $5^{\circ} \mathrm{C} /$ min. Two replicates of oil samples were processed in the same way. Relative component concentration was calculated based on GC peak areas without correction factors. The injection volume of the $M$. alternifolia (tea tree) essential oil was $1 \mu \mathrm{L}$ (Boligon et al., 2013).
Gas chromatography mass (GC-MS) analyses were performed on an Agilent Technologies Auto System $\mathrm{XL}$ GC-MS system operating in the El mode at $70 \mathrm{eV}$, equipped with a split/split less injector $\left(250^{\circ} \mathrm{C}\right)$. The transfer line temperature was $280^{\circ} \mathrm{C}$. Helium was used as carrier gas $(1.5 \mathrm{~mL} / \mathrm{min})$ and the capillary columns used were a HP 5MS $(30 \mathrm{~m} \times 0.25 \mathrm{~mm}$; film thickness of $0.25 \mathrm{~mm})$ and a HP Innowax $(30 \mathrm{~m} \times 0.32 \mathrm{~mm}$ i.d., film thickness of $0.5 \mathrm{~mm}$ ). The temperature program and the injected volume of oil were the same as used for GC analyses. The injected volume of the essentials oils was $1 \mu \mathrm{L}$. Component identification of both oils was based on the retention index (RI), using as reference of the homologous series of $n$-alkanes, $C_{7}-C_{30}$, under identical experimental conditions, and comparing with the mass spectra library search (NIST and Wiley), and with the mass spectra literature data (Adams, 1995). The relative amounts of the individual components were calculated based on the CG peak area (FID response).

\section{Lesser mealworms}

Lesser mealworms larvae (L8) and adults were obtained from naturally infested poultry farms located in the city of Concordia, State of Santa Catarina, Brazil. On the farms, insects were manually collected, placed in plastic bottles, and transported to the laboratory, where they were reared under controlled conditions $\left(25^{\circ} \mathrm{C} ; 70 \%\right.$ R.H. $)$. The insects were kept in plastic pots with poultry litter and wet cottons, and were fed with poultry feed.

\section{Bioassays}

In-vitro tests were conducted using test solutions prepared with pure TTO, nanoparticles, and terpinen4-ol. Pure TTO was first dissolved in Triton solution $(1: 1)$ and then diluted in water to the concentrations of $1,5,10,25,50$, and $100 \%$. TTO nanoparticles were dissolved in water to the concentrations of 1,3 , and $7.5 \%$. Terpinen-4-ol was dissolved only in water to the same concentrations as TTO. The solutions $(300 \mu \mathrm{L})$ were added to filter paper-lined Petri dishes according to a completely randomized design and three replicates per treatment at $25{ }^{\circ} \mathrm{C}( \pm 3)$ and $70 \%( \pm 10)$ relative humidity, and submitted to a photoperiod of $12: 12$ (L:D). Three controls were used, and included watertreated mealworms, Triton-treated mealworms and nanoparticle-treated mealworms (only the capsule of cetyl palmitate and polysorbate 80).

\section{Larvae and adults}

Ten $8^{\text {th }}$ instar larvae or adults were placed in a Petri dish. Solutions were then added and the dishes were 
Volpato A, Lorenzetti WR, Zortea T, Giombelli LCDD, Baretta D,

Santos RC, Vaucher RA, Raffin RP,

Souza ME, Stefani LM, Boligon AA

Athayde ML, Silva AS da

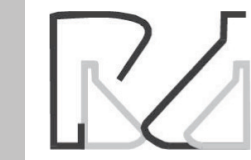

transferred to an incubator with controlled environment $\left(25^{\circ} \mathrm{C} ; 70 \%\right.$ R.H.). The percentage of live larvae was monitored daily for 13 days. The percentage of live lesser mealworm adults on each disk was monitored daily for 24 or 31 days.

\section{Ecotoxicity tests}

The evaluation of the effect of TTO on soil organisms was performed by standard ecotoxicological tests (ISO 1999, ISO 2010) with the springtail species Folsomia candida. The springtails were obtained from cultures of the Laboratory of Soil and Sustainability at the University of the State of Santa Catarina (UDESC) and kept under controlled conditions at $20 \pm 2{ }^{\circ} \mathrm{C}$, and a photoperiod of 16:8 (L:D).

This study was conducted using the tropical artificial soil (TAS) method, with humidity set at $65 \%$ of retention capacity and $\mathrm{pH}$ adjusted to $6.0 \pm 0.5$. The treatments consisted of TAS enriched with TTO in the laboratory. Similarly to the in-vitro tests, the TTO was previously mixed with Triton solution (1:1), and the final doses were obtained by diluting this mixture with distilled water.

For survival tests, the soil was exposed to six concentrations of TTO $(1,5,10,25,50$ and $100 \mathrm{mg}$ $\mathrm{kg}^{-1}$ ) using four replicates per concentration. Each plastic recipient contained $50 \mathrm{~g}$ of soil, to which 10 springtails were added, along with $2 \mathrm{mg}$ of dried granular baker's yeast. The containers were opened to allow air contact for three seconds three times weekly, and $2 \mathrm{mg}$ of dry yeast granules were added
Melaleuca alternifolia Essential Oil against the Lesser Mealworm (Alphitobius diaperinus) and Its Possible Effect on the Soil Fauna

again after 14 days of incubation. At the end of 28 days of testing, the contents of each test vessel was poured into a beaker of water. A few drops of blue ink were gently added and homogenized. The floating springtails were counted and missing adults were considered dead.

TTO concentrations used in the reproduction test were the same as those applied in the survival test. This test followed the procedures described by ISO (1999), and the methodology was based on the survival test, i.e., larvae that floated in the water were photographed for better counting.

\section{Statistical analysis}

The normality test was applied for the results of the bioassays with the lesser mealworm, and data showed normal distribution. Data were then submitted to analysis of variance (ANOVA) and Duncan test $(p<0.05)$. The data on springtail survival and reproduction were subjected to ANOVA followed by Dunnett test $(p<0.05)$. Untreated lesser mealworms were used as control group.

\section{RESULTS}

\section{Components present in the essential oil of tea tree}

The results of the components found in the TTO oil are shown in Table 1. The three main compounds were identified as terpinen-4-ol, $\boldsymbol{\gamma}$-terpinene, and $\alpha$-terpineol.

Table 1 - Qualitative and quantitative analyses of Melaleuca alternifolia essential oil (TTO) used in this study.

\begin{tabular}{|c|c|c|c|c|c|c|}
\hline Peak & Compounds & $\mathrm{Rl}^{\mathrm{a}}$ & $\mathrm{RI}^{\mathrm{b}}$ & Amount (\%) & ISO4730 range (\%) & Mol. Formule \\
\hline 1 & $\alpha$-pinene & 937 & 939 & 3.51 & $1-6$ & $\mathrm{C}_{10} \mathrm{H}_{16}$ \\
\hline 2 & Sabinense & 976 & 976 & 0.46 & Tr-3.5 & $\mathrm{C}_{10} \mathrm{H}_{16}$ \\
\hline 3 & $\alpha$-terpinene & 1016 & 1018 & 9.85 & $5-13$ & $\mathrm{C}_{10} \mathrm{H}_{16}$ \\
\hline 4 & p-cymene & 1025 & 1026 & 2.27 & $0.5-8.0$ & $\mathrm{C}_{10} \mathrm{H}_{14}$ \\
\hline 5 & Limonene & 1032 & 1031 & 1.39 & $0.5-1.5$ & $\mathrm{C}_{10} \mathrm{H}_{16}$ \\
\hline 6 & 1.8-cineole & 1037 & 1038 & 6.03 & Tr-15 & $\mathrm{C}_{10} \mathrm{H}_{18} \mathrm{O}$ \\
\hline 7 & $\gamma$-terpinene & 1062 & 1062 & 20.15 & $10-28$ & $\mathrm{C}_{10} \mathrm{H}_{16}$ \\
\hline 8 & terpinen-4-ol & 1178 & 1177 & 41.98 & $30-48$ & $\mathrm{C}_{10} \mathrm{H}_{18} \mathrm{O}$ \\
\hline 9 & Terpinolene & 1089 & 1088 & 4.17 & $1.5-5$ & $\mathrm{C}_{10} \mathrm{H}_{16}$ \\
\hline 10 & $\alpha$-terpineol & 1190 & 1189 & 2.43 & $1.5-8$ & $\mathrm{C}_{10} \mathrm{H}_{18} \mathrm{O}$ \\
\hline 11 & Aromadendrene & 1440 & 1439 & 1.04 & Tr-3 & $\mathrm{C}_{15} \mathrm{H}_{24}$ \\
\hline 12 & Ledene & 1521 & 1525 & 0.80 & Tr-3 & $\mathrm{C}_{15} \mathrm{H}_{24}$ \\
\hline 13 & $\delta$-cadinene & 1539 & 1538 & 0.63 & Tr-3 & $\mathrm{C}_{15} \mathrm{H}_{24}$ \\
\hline 14 & Globulol & 1583 & 1583 & 0.97 & Tr-1 & $\mathrm{C}_{15} \mathrm{H}_{26} \mathrm{O}$ \\
\hline \multirow[t]{2}{*}{15} & viridiflorol & 1591 & 1590 & 0.18 & Tr-1 & $\mathrm{C}_{15} \mathrm{H}_{26} \mathrm{O}$ \\
\hline & Total identified (\%) & & & 95.86 & & \\
\hline
\end{tabular}

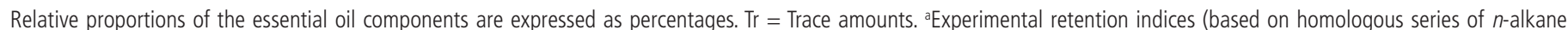
$C_{7}-C_{30}$ ). ${ }^{b}$ Retention indices from literature (Adams, 1995). International Organization for Standardization (ISO), standard number 4730. 
Volpato A, Lorenzetti WR, Zortea T, Giombelli LCDD, Baretta D,

Santos RC, Vaucher RA, Raffin RP,

Souza ME, Stefani LM, Boligon AA

Athayde ML, Silva AS da

\section{TTO nanoparticles}

The TTO nanoparticles were evaluated for their physical and chemical properties. The particle size was $287( \pm 2 \mathrm{~nm})$ and polydispersity index of $0.2( \pm 0.022)$ with a zeta potential of-14,2 $\pm 1,7 \mathrm{mV}$.

\section{In-vitro tests}

The three controls were used this study (watertreated mealworms, triton-treated mealworms and nanocapsule-treated mealworms) validated in vitro tests, i.e., water, triton and nanocapsule are not harmful to lesser mealworm larvae or adults. The controls are described below each Figure.

\section{TTO oil}

The results of the percentage of live adults and larvae are presented in Figure 1. The tests lasted 13 days for larvae, and 31 days for adults. The larvae were not affected by TTO at $1 \%$, similarly to what was observed in the control group (Fig. 1a). A significant percentage of larval mortality (over 60\%) was observed with $10 \%$ of TTO. TTO was efficient to eliminate all larvae at 25,50 , and $100 \%$, demonstrating great larvicidal potential. The mortality rate was lower in adults when compared with the larvae, i.e., 40\% adult mortality was observed with TTO at 50\% (Fig. 1b). Adult mortality was not significantly different among lower TTO concentrations (1, 5, 10, and 25\%); however, TTO
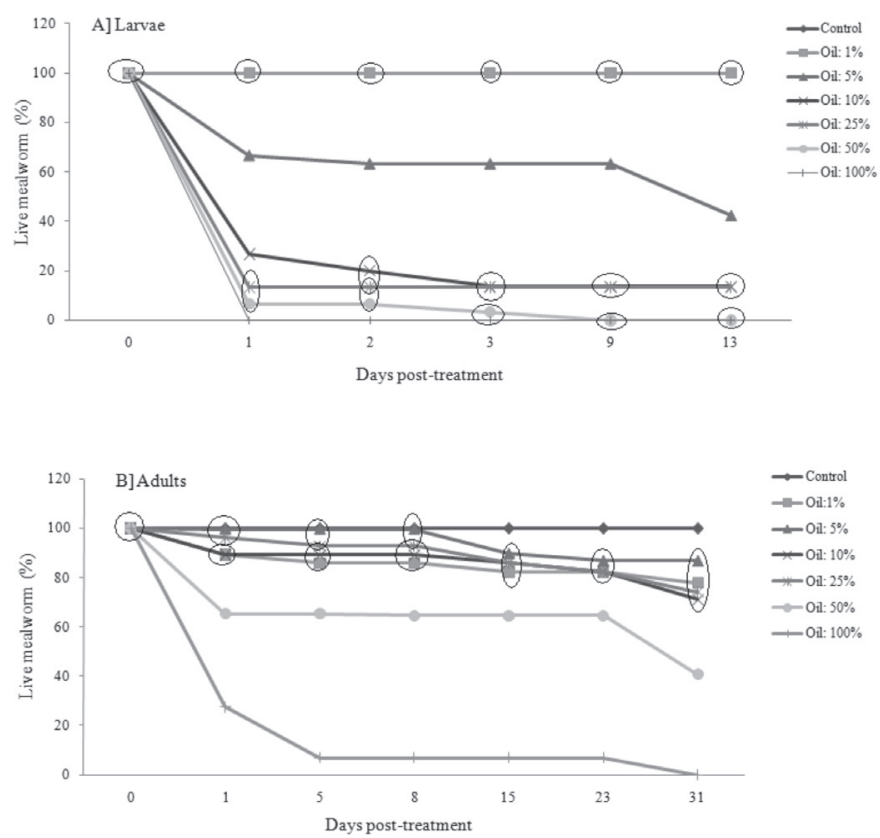

Figure 1 - Percentage of live larvae $(A)$ and adults (B) of Alphitobius diaperinus after treatment with Melaleuca alternifolia essential oil $(1,5,10,25,50$, and 100\%). Means within a circle are similar by the Duncan's test ( $p>0.05)$. "Control" used to triton-treated lesser mealworms.
Melaleuca alternifolia Essential Oil against the Lesser Mealworm (Alphitobius diaperinus) and Its Possible Effect on the Soil Fauna

concentrations of 50 and $100 \%$ demonstrated high insecticidal effect. In adults, observations were carried out until 50 days, but no changes were observed after 31 days; therefore, only data until 31 days were included in the analyses.

\section{TTO nanoparticles}

TTO nanoparticles had no effect on $A$. diaperinus larvae and adult when compared with the control group, independent of the concentration (Figure 2). The experimental periods were 13 days for the larvae and 24 days for the adults. Thus, TTO nanoparticles had neither larvicidal nor insecticidal effect at these concentrations.

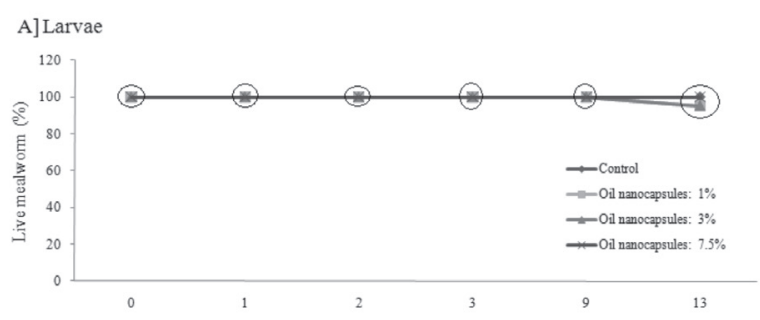

B] Adults

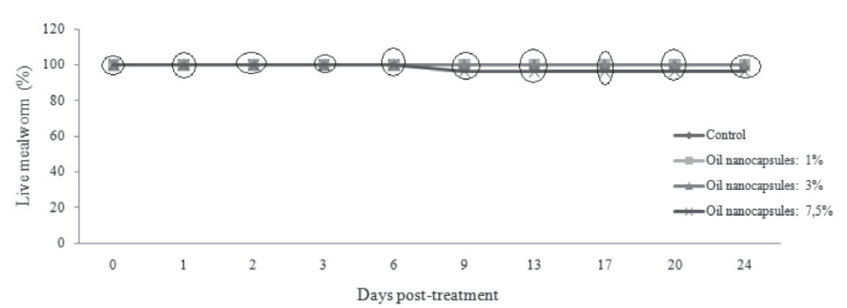

Figure 2 - Percentage of live larvae (A) and adults (B) of Alphitobius diaperinus after treatment with Melaleuca alternifolia nanoparticles (1,3, and 7.5\%). Means within a circle are similar by the Duncan's test ( $p>0.05)$. "Control" used refers to nanoparticle-treated lesser mealworms (only the capsule of cetyl palmitate and polysorbate 80).

\section{Terpinen-4-ol}

The results obtained with terpinen-4-ol were similar to those verified with pure TTO (Figure 3). Terpinen-4ol at 1,5 , and $10 \%$ promoted similar results as those of the control group (Fig. 3a), whereas concentrations of 25,50 and $100 \%$ had both larvicidal and insecticidal effects (Fig. 3b).

\section{Ecotoxicity tests}

The results of springtail survival and reproduction tests are reported in Figure 4. TTO had no lethal effect on the adult springtails submitted to the survival test, which indicates it is not toxic to the soil fauna. The reproduction test showed no statistical differences among the treatments. TTO doses of 10 and $25 \mathrm{mg}$ $\mathrm{kg}^{-1}$ resulted in the lowest number of juveniles, despite the lack of statistical differences ( $p>0.05)$. 
Volpato A, Lorenzetti WR, Zortea T, Giombelli LCDD, Baretta D,

Santos RC, Vaucher RA, Raffin RP,

Souza ME, Stefani LM, Boligon AA

Athayde ML, Silva AS da
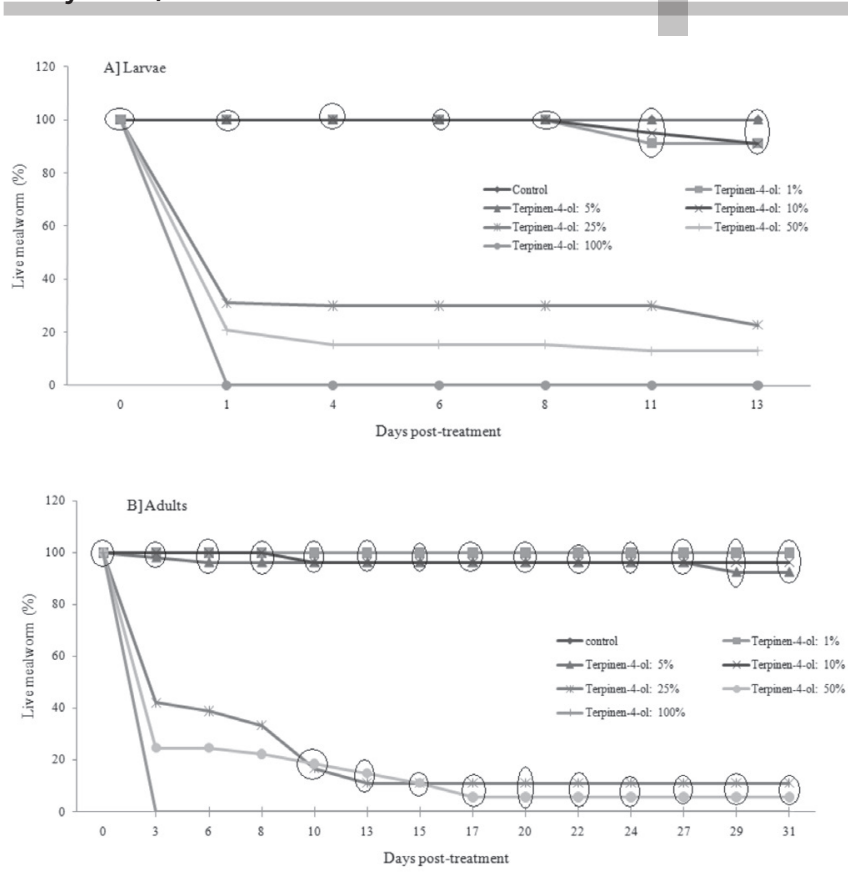

Figure 3 - Percentage of live larvae $(A)$ and adults (B) of Alphitobius diaperinus after treatment with terpinen-4-ol (1, 5, 10, 25, 50, and 100\%). Means within a circle are similar by the Duncan's test ( $p>0.05)$. "Control" refers to water-treated lesser mealworms.

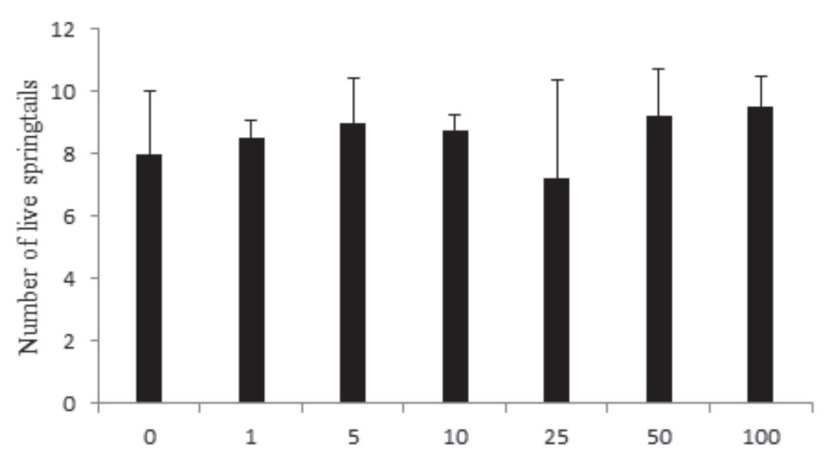

A] Concentrarions of tea tree in soil $(\mathrm{mg} / \mathrm{kg})$

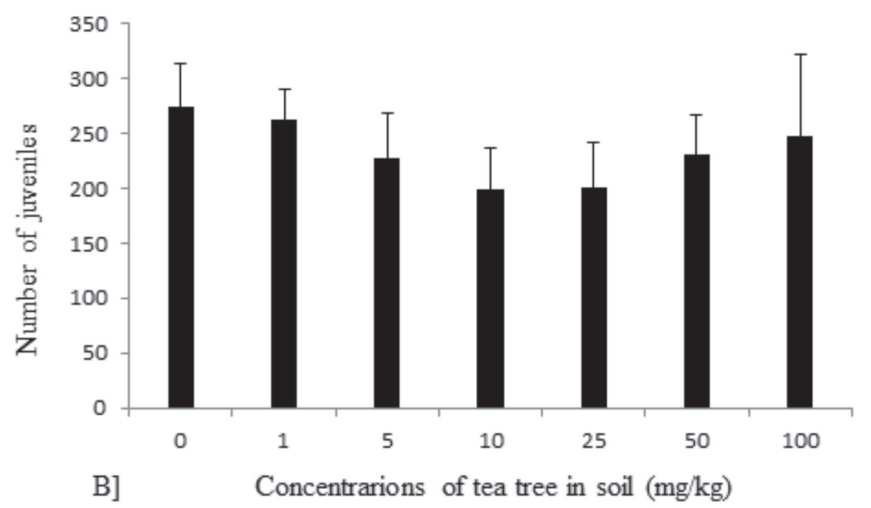

Figure 4 - Survival (A) and reproduction (B) tests with Folsomia candida exposed to tropical artificial soil (TAS) with different concentrations of Melaleuca alternifolia essential oil (TTO - tea tree oil). Treatments were similar by the Dunnet's test ( $p>0.05)$.
Melaleuca alternifolia Essential Oil against the Lesser Mealworm (Alphitobius diaperinus) and Its Possible Effect on the Soil Fauna

\section{DISCUSSION}

The lesser mealworm control in poultry houses is typically controlled by an intense use of chemicals; however, these insects eventually become resistant to these products (Chernaki-Leffer et al., 2011). This has motivated the search for efficient alternative control methods and that also have lower environmental impact. These requirements can be met using natural products, including essential oils, which have attracted the interest of many researchers (Prado et al., 2013; Pazinato et al., 2014; Klauck et al., 2014).

In the present study, we showed for the first time the efficacy of $M$. alternifolia oil against both larval and adult forms of the lesser mealworm, with promising results. TTO showed potent larvicidal effect at concentrations greater than $10 \%$, as well as against adults at concentrations greater than $25 \%$. It is likely that the mortality of the lesser mealworm with the use of pure oil was related to the presence of its main compound, known as terpinen-4-ol, which promoted results similar to TTO when tested alone. However, we cannot exclude the application of other compounds, which may act in synergism for the control of this pest. Other oil compounds, such as thymol and carvacrol, have been shown to have strong toxic properties on some parasites (Szczepanik et al., 2012).

Studies have demonstrated that $M$. alternifolia oil has toxic effects against horn flies (Haematobia irritans), and repelent effect at concentration of $5 \%$ (Klauck et al., 2014). In addition, TTO has acaricidal effect on cattle ticks (Rhipicephalus microplus), and damages their reproductive system, both in its pure and nanoparticle forms, but the nanoparticles potentiated its lethal effect (Pazinato et al., 2014), which was not observed in this study with $A$. diaperinus. Nanotechnology has been used to improve the efficiency of essential oils and to reduce the need for large oil volumes (Martinez et al., 2011).

Other studies have shown insecticidal effect of different essential oils on some $A$. diaperinus life stages. Tests demonstrated that thyme essential oil (Thymus vulgaris) was harmful to this insects, as well as when two compounds (carvacrol and thymol) of this oil were individually tested (Szczepanik et al., 2012). Anise oil (Illiciumverum) showed 100\% efficacy against A. diaperinus larvae and adults at the concentrations of $3.12,6.25,12.5$, and $25.0 \mathrm{mg} \mathrm{ml}_{-1}$ (Szczepanik \& Szumny, 2011), similarly to the effects obtained with the higher TTO concentrations used in the present study. Our findings suggest that other formulations of the oil, in addition of nanoparticles, may be useful and need to 
Volpato A, Lorenzetti WR, Zortea T, Giombelli LCDD, Baretta D,

Santos RC, Vaucher RA, Raffin RP

Souza ME, Stefani LM, Boligon AA

Athayde ML, Silva AS da
Melaleuca alternifolia Essential Oil against the Lesser Mealworm (Alphitobius diaperinus) and Its Possible Effect on the Soil Fauna be tested both in-vitro and under field conditions, since no toxicity to the soil fauna was detected.

Cypermethrin is the main insecticide used to control A. diaperinus; however, this drug may be toxic to the soil fauna (Styrishave et al., 2010; Zortéa et al., 2015), and consequently cause environmental damage. Therefore, it is important to evaluate the environmental impact of new treatments because contamination may affect many ecology systems. In the present study, the $M$. alternifolia oil had no significant toxic effect on the soil fauna, differently from the essential oil of $E$. globulus, which resulted in a $76 \%$ reduction in reproduction of $F$. candida at $60 \mathrm{mg} \mathrm{kg}^{-1}$ (Martins et al., 2013). The overall results of the present study show that poultry litter can be used as organic fertilizer after TTO application to control A. diaperinus.

\section{CONCLUSIONS}

Both TTO and terpinen-4-ol have insecticidal and larvicidal effect against the lesser mealworm $A$. diaperinus. In addition, it was demonstrated that TTO does not negatively affect the soil fauna, and consequently, there is no environmental impact when this essential oil is mixed with soil. Therefore, the tea tree oil is an option to control of $A$. diaperinus, particularly its larval stage.

\section{REFERENCES}

Adams RP. Identification of essential oil components by Gas Chromatography/ Mass spectroscopy. Illinois; Allured Publishing Corporation; 1995.

Baldissera MD, Da Silva AS, Oliveira CB, Santos RCV, Vaucher RA, Raffin RP, Gomes P, Dambros MGC, Miletti LC, Boligon AA, Athayde ML, Monteiro SG. Trypanocidal action of tea tree oil (Melaleuca alternifolia) against Trypanosoma evansi in vitro and in vivo used mice as experimental model. Experimental Parasitology 2014; 141(1):21-27.

Boligon AA, Schwanz TG, Piana M, Bandeira RV, Frohlich JK, Brum TF, Zadra $\mathrm{M}$, Athayde ML. Chemical composition and antioxidant activity of the essential oil of Tabernaemontana catharinensis A. DC. leaves. Natural Product Research 2013; 27(1):68-71

Carson CF, Riley TV. Antimicrobial activity of the essential oil of Melaleuca alternifolia. Letter Applied Microbiology 1993; 16(1):49-55.

Chernaki-Leffer AM, Sosa-Goméz DR, Almeida LM, Lopes ION. Susceptibility of Alphitobius diaperinus (Panzer) (Coleoptera, Tenebrionidae) tocypermethrin, dichlorvos and triflumuron in southern Brazil. Revista Brasileira de Entomologia 2011; 55(1):125-128.

Da Silva AS da, Hoff G, Doyle RL, Santurio JM, Monteiro SG. Ciclo biológico do cascudinho Alphitobius diaperinus em laboratório. Acta Scientiae Veterinariae 2005; 33(2):177-181.

Gazoni FL, Flores F, Bampi RA, Silveira F, Boufleur R, Lovato M. Avaliação da resistência do cascudinho (Alphitobius diaperinus) Panzer (Coleoptera: Tenebrionidae) a diferentes temperaturas. Arquivos do Instituto Biologico 2012; 79(1):69-74

ISO. Soil quality-inhibition of reproduction of Collembola (Folsomia candida) by soil pollutants [ISO 11267]. Geneva; International Organization for Standardization; 1999.
ISO. Soil quality-avoidance test for determining the quality of soils and effects of chemicals on behavior - Part 2: Test with collembolans (Folsomia candida) [ISO 17512-2]. Geneva; International Organization for Standardization; 2010.

Klauck V, Pazinato R, Stefani LM, Santos RC, Vaucher RA, Baldissera MD, Raffin R, Boligon A, Athayde M, Baretta D, Machado G, Da Silva AS. Insecticidal and repellent effects of tea tree and andiroba oils on flies associated with livestock. Medical and Veterinary Entomology 2014; 28(1):33-39.

Martinez HR. Aplicación de la alternifolia a em alternifolia: nanoodontología. CES Odontology 2011; 24(2):87-91

Martins C, Natal-da-Luz T, Sousa JP, Gonçalves MJ, Salgueiro L, Canhoto C. Effects of essential oils from Eucalyptus globulus leaves on soil organisms involved in leaf degradation. PLoS ONE 2013; 8(4):e61233

Mulla MS, Su T. Activity and biological effects of neem products against arthropods of medical and veterinary importance. Journal American Mosquitoes Control Association 1999; 15(2):133-152.

Neves RCSM, Ferraz RHS, Mendonça AJ, Lima SR, Cruz FAS, Rosa JG, Mateus LAF, Ferraz V, Barros LA. Acaricide effect of the Melaleuca alternifolia essential oil on Otodectescynotis. Revista Brasileira de Ciências Veterinária 2012; 19(3):144-148.

Pazinato R, Klauck V, Volpato A, Santos RC, De Souza ME, Vaucher RA, Raffin R, Gomes P, Felippi CC, Stefani LM, Da Silva AS. Influence of tea tree oil (Melaleuca alternifolia) on the cattle tick Rhipicephalus microplus. Experimental Applied Acarology 2014; 63(1):77-88

Prado GP, Stefani LM, Silva AS da, Smaniotto LF, Garcia FRM, De Moura NF. Alphitobius diaperinus (Coleoptera: Tenebrionidae) susceptibility to Cunila angustifolia essential oil. Journal of Medical Entomology 2013; 50(5):1040-1045.

Roco MC. International strategy for nanotechnology research and development. Journal of Nanoparticle Research 2001; 3(5):353-360.

Santos MJG, Ferreira FML, Cachada A, Duarte AC, Sousa JP. Pesticide application to agricultural fields: effects on the reproduction and avoidance behaviour of Folsomia candida and Eisenia andrei. Ecotoxicology 2012; 21(8):2113-2122.

Santos JC, Alves LFA, Opazo MAU, Mertz NR, Marcomini AM, Oliveira DGP, Bonini AK. Eficiência da aplicação de inseticida químico no solo para o controle de Alphitobius diaperinus Panzer (Coleoptera: Tenebrionidae) em aviário de frango de corte. Arquivos do Instituto Biologico 2009; 76(3):417-425.

Styrishave B, Hartnik T, Christensen P, Andersen O, Jensen J. Influence of soil type and organic matter content on the bioavailability, accumulation, and toxicity of a-cypermethrin in the springtail $F$. candida. Environmental Toxicology and Chemistry 2010; 29(5):1084-1090

Szczepanik M, Szumny A. Insecticidal activity of star anise (Illicum verum Hook. F.) fruits extracts against lesser mealworm, Alphitobius diaperinus Panzer (Coleoptera: Tenebrionidae). Allelopathy Journa $2011 ; 27(2): 277-288$

Szczepanik M, Zawitowska B, Szumny A. Insecticidal activities of Thymus vulgaris essential oil and its components (thymol and carvacrol) against larvae of lesser mealworm, Alphitobius diaperinus Panzer (Coleoptera: Tenebrionidae). Allelopathy Journal 2012; 30(1):129-142

Walton SF, McKinnon M, Pizzutto S, Dougall A, Williams E, Currie BJ. Acaricidal activity of Melaleuca alternifolia (tea tree) oil: in vitro sensitivity of Sarcoptes scabiei var hominis to terpinen-4-ol. Archives Dermatology 2004; 140(5):563-566.

Zortéa T, Baretta D, Maccari AP, Segat JC, Boiago ES, Sousa JP, Da Silva AS. Influence of cypermethrin on avoidance behavior, survival and reproduction of Folsomia candida in soil. Chemosphere 2015; 122(1):94-98 